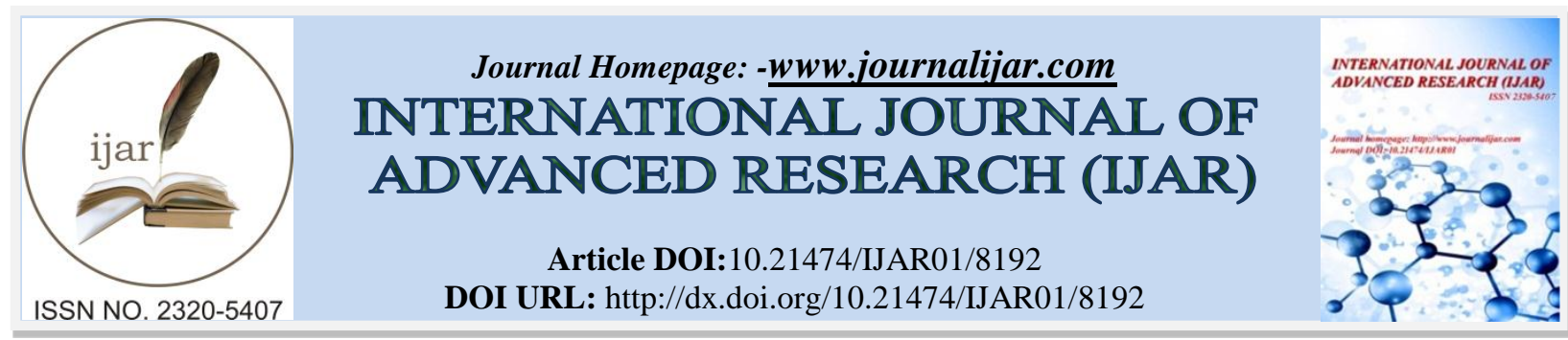

RESEARCH ARTICLE

\title{
EFFECTIVENESS OF SELF-HELP GROUPS (SHGS) IN EMPOWERING RURAL WOMEN IN BATTICALOA DISTRICT OF SRI LANKA.
}

\author{
Arunasalam Sureshkumar ${ }^{1}$ and Saravanamutthu Jeyarajah ${ }^{2}$. \\ 1. Monitoring and Evaluation Specialist, World Vision Lank, Sri Lanka. \\ 2. Senior Lecturer, Department of Economics, Eastern University, Sri Lanka. Lanka.
}

\section{Manuscript Info}

\section{Manuscript History}

Received: 10 October 2018

Final Accepted: 12 November 2018

Published: December 2018

Keywords:-

Self-Help Groups, women, socioeconomic empowerment, income, saving and employment.

\begin{abstract}
The self-help group (SHG) approach is a crucial tool to eliminate poverty and improve the status of women entrepreneurship and financial support for the better means of living. The aim of this paper was to examine the effectiveness of the self-help groups in promoting the socio-economic empowerment of rural women in selected divisional secretariat division of Batticaloa district of Sri Lanka. Primary data was collected through a structured questionnaire, discussion and observations of the SHGs in the villages located in the Eravur Pattu DS division. A total of 69 of members of SHGs were randomly selected for the study. Descriptive statistics and Likert scale method were employed to analyze the collected data. The study showed positive impact on the economic empowerment of women in relation to income, employment and savings, access to credit and training after joining the SHG and also found the significant positive impact on social empowerment of women regarding the decision making, community participation and leadership qualities such as communication, self-confidence, managerial skill and organizing skill. Thus the study concluded that the SHGs have highly contributed towards promoting the socio-economic empowerment of rural women in the study area and it also proved to be instrumental in empowering rural women.
\end{abstract}

Copy Right, IJAR, 2017, All rights reserved.

\section{Introduction:-}

Background of the Study:-

The self-help group (SHG) is a small group of rural poor, who have voluntarily come forward to form a group for the improvement of the social and economic status of the members. SHG is also a viable organized set up to disburse microcredit to the rural women and encouraging them together into entrepreneurial activities. (Abdul, 2007). Many scholars Christuraj P and Saraswathy S (2009), Sita Devi K et al, (2011)Thangamani,(2013). confirmed in their studies that SHGs are playing a crucial role to provide microfinance to the rural poor especially women and SHGs impacts positively on their members in terms of empowerment, accessibility to credit, and socioeconomic change etc.The concept of empowerment is defined as the process by which women take control and ownership of their choices. The core elements of empowerment have been defined as an agency, awareness of gendered power structures, self-esteem, and self-confidence (Kabeer, 2001). Empowerment can take place at

Corresponding Author:-Arunasalam Sureshkumar.

Address:-Monitoring and Evaluation Specialist, World Vision Lank. 
different levels such as individual, household, community and societal by providing encouraging factors and removing constraining factors. In this connection, Self Help Groups play an effective role in promoting women empowerment. Bosch, (2002) reported that SHG is an efficient tool to fight against poverty. It is also a way of promoting the empowerment of the most marginalized peoples, especially women. SHGs at the village level is gradually becoming an important concept in Sri Lanka and the various constructive activities that can be undertaken to enhance the economic conditions of concerned members and boost their social status. Rural women in Sri Lana are observed as the most vulnerable group in society. EravurPattuDivisional Secretariat division is one of the underdeveloped divisions of Batticaloa district, where the status of rural women in every aspect is a concerning issue. They face many socio-economic problems such as low income, unemployment, lack of confidence in their potential, having limited access to all kinds of resources such as education, financial support to start a business enterprise, transportation, awareness training, availability of current information etc. but have more hidden talents, which have to be bought into light. Further, the government and Non-government Organizations implemented various development programs to develop the socio-economic condition of rural women in the particular area. However, the aspect of the empowerment of women was not properly addressed. it is vital to change their capacity to work by giving them the necessary training on income generating activities, supporting them with financial facilities, bringing their talents into the light, giving them marketing knowledge, current information etc. which helps in increasing knowledge, enriching their skills and improve their socio-economic status through the Self-help Groups. Hence, there is a need to study "how Self Help Group approach has resulted in empowering socioeconomic status of the rural women of EravurPattuDivisional Secretariat division of Sri Lana?

\section{The objective of the study:-}

The overall objective of the study is to examine the effectiveness of the Self-help Group in promoting the socioeconomic empowerment of rural women in the selected divisional secretariat division of Batticaloa district of Sri Lanka.

\section{Materials and Methods:-}

This study is heavily depended on the primary data which were collected from a sample questionnaire survey. The questionnaire survey was administered in the form of interviews. Eravur Pattu DS division of Batticaloa district was selected as a study area, and the sample was selected from particular GN division. Descriptive and Likert scale method was used in the study. The selection of sample is confined only to rural women who are the members of Self Help Group in the selected division. Ten GramaNiladhari (GN) divisions such as Thalawai, Savukkady, Iyankerny, Pankudavely, Kaluwankerny-1, Mavadivembu-1, Sittandy-4, Koduwamadu, Veppavettuwan, and KumaraveliyarKiramam were selected for the study where Self Help Groups are functioning more than five years. It was planned to choose the respondents from the Self Help Group in all the communities of selected GN divisions.

After the field survey, the entire survey schedule was thoroughly scrutinized to correct the inconsistencies in responses and edited. Then, all the data collected were coded and processed so as to have the required tables and results of statistical proof. The following tools and techniques were used to analyze the data.

Five-pointLikert's scale was used to analyze the effectiveness of SHGs in promoting the socio-economic empowerment of women. To study the empowerment of sample SHG members, 34 statements are framed and for each statement, Likert'sfive-point scale has been used. By using this scale the scores intensity value has been calculated for each statement. 


\section{Conceptualization:-}

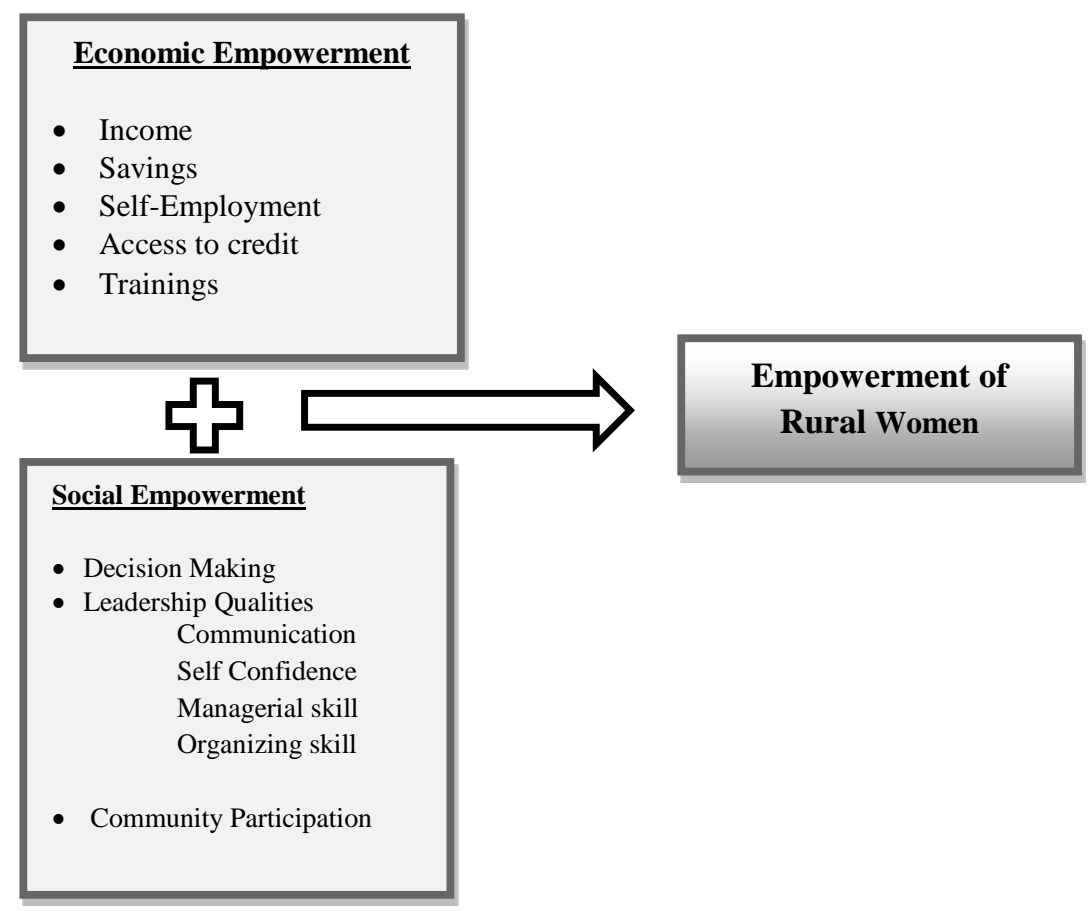

Figure 1:-Conceptualization Framework

\section{Results and Discussion:-}

EravurPattuDivisional Secretariat division is falling within the district of Batticaloa. The study area is located between $7^{\circ} 25^{\prime}$ to $8^{\circ} 15^{\prime} \mathrm{N}$ latitude and $81^{\circ} 15^{\prime}$ to $81^{\circ} 45^{\prime} \mathrm{E}$ longitude covering an area of about $634.16 \mathrm{Km}^{2}$ forming $24 \%$ of the total land area of the district. This division consists of 203 Villages in 39 GramaNiladhari Divisions with the population of 74,036, belonging to all 3 Communities namely Tamil, Muslim \& Sinhalese. The main occupation of the people is agriculture, cattle, farmer and fishing. Most of the people are living below the poverty line because there consistently affected by a natural and unnatural disaster like Tsunami, Flood, and drought.

Table 1:-Socio Economic Parameters of Respondents

\begin{tabular}{|l|c|}
\hline \multicolumn{1}{|c|}{ Variable } & Percentage \\
\hline Age of the Respondents & $13 \%$ \\
\hline 18-30 Years & $44 \%$ \\
\hline 31-40 Years & $33 \%$ \\
\hline 41-60 Years & $10 \%$ \\
\hline Over 50 & $98.6 \%$ \\
\hline Civil Status & $1.4 \%$ \\
\hline Married & \\
\hline Wamily Size & $22 \%$ \\
\hline Up to 3 members & $66 \%$ \\
\hline 3-5 members & $12 \%$ \\
\hline More than 5 members & \\
\hline Level of Education & $03 \%$ \\
\hline Illiterate & $29 \%$ \\
\hline Primary & \\
\hline
\end{tabular}




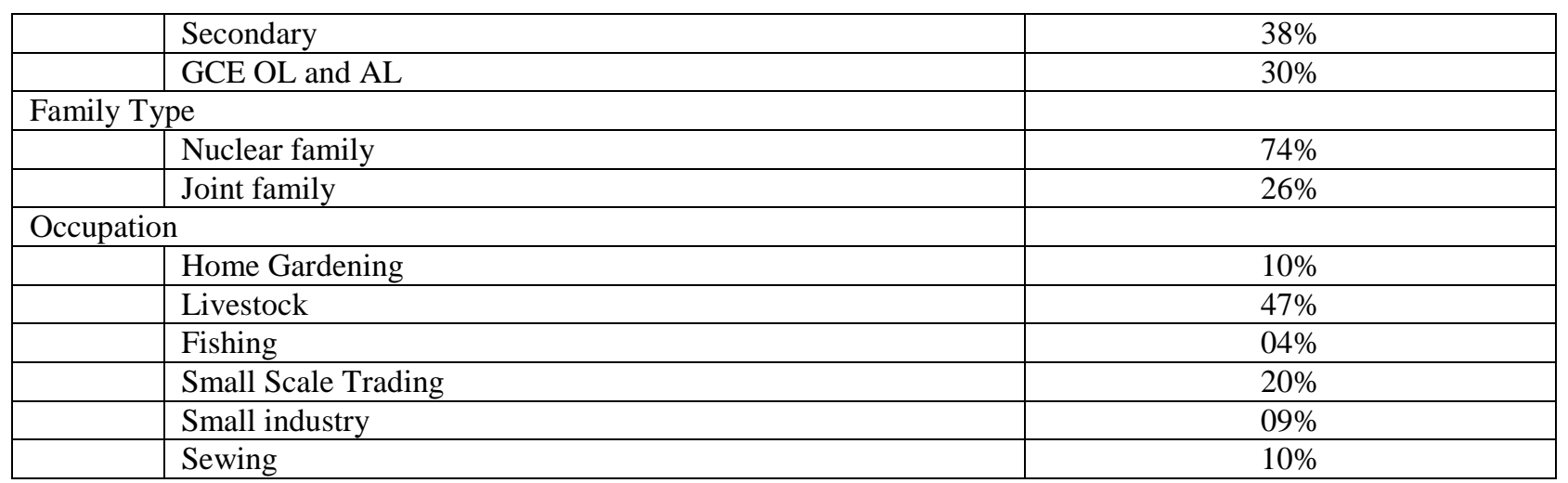

Source:-Field Survey

Nearly $44 \%$ of the respondent belong to the age group of $31-40$, more than three fourth $(33 \%)$ is in the age group of more than 41 years and the remaining $13 \%$ and in the age group of $18-30$ and above 50 respectively. it can understand that in the study area the Self Help Groups attract more of the women from the age group of 31-40 when compared to the other age groups. Moreover, a sizable proportion of the respondents (98.6\%) are married and the remaining $1.4 \%$ is windows. it clearly says that a number of married women do join in Self-Help Groups with a belief of bringing desirable changes in their lives. Therefore, it could also be interpreted that members who are married are largely interested in the formation and promotion of SHGs. Education is considered an effective tool to empower women. Because it has the capability to increase mental strength and knowledge and it develops the personality of human being. The finding shows that more than one-third of the respondents (38\%) fall under the education level of Grade 7-10. More than one-fourth of the respondents (27 \%) have studied up to G.C.E (O/L). The $29 \%$ of the sample respondents completed the education level of Grade 1-6.3\% of the respondents have studied up to G.C.E (A/L) and 3\% of the respondents are illiterate. It is evident that 74 percent belongs to nuclear families and the remaining respondents belong to joint families. The results show that a few less than half proportions of the respondents (47\%) engage in the livestock, nearly one-fifth of the respondents $(20 \%)$ involve in the small-scale trading, $10 \%$ of the respondents engage in the home gardening and sewing respectively. $9 \%$ of the respondents are engaging in the small industries, and the remaining $4 \%$ involve in the fishing. The Self Help Groups are providing space for women to develop themselves and their respective families.

The results revealed that $46.4 \%$ members of SHGs were satisfied with the increased income while $47.8 \%$ of the respondents were moderately satisfied with the increased income. $5.8 \%$ of the respondents dissatisfied with the increased income. It was also notable that saving of households was identified as an important variable for the success of SHGs. The results show that no one dissatisfied with their increased saving while $29 \%$ of the respondents moderately satisfied with the increased saving. The highest number of respondents (71\%) satisfied with the increased saving.

The variable of self-employment after the intervention of the Self Help Groups illustrates that $4.3 \%$ of the respondents were not self -employed while $32 \%$ of the respondents were self-employed with moderately satisfied. Moreover, $63.7 \%$ were satisfied with the self-employment. Access to credit facilities was another variable in the study. Results indicate that credit access encourages women's self-employment. Most of the respondents (78.2\%) are satisfied with the access to credit in this study. This shows that most of them have obtained credit to their selfemployment. only $5.8 \%$ of the respondents are dissatisfied with access to credit. $16 \%$ of the respondents are moderately satisfied with the access to credit in the study area.

Skills development is key to improving household productivity, employability and income-earning opportunities for women and also for enhancing sustainable rural development and livelihoods. Training also selected one of the variables in the study. Training received for the development of their business, $2.9 \%$ of the respondents are dissatisfied with regard to the training. $37.7 \%$ of the respondents are moderately satisfied with the training received. More than half $(59.4 \%)$ of the respondents are satisfied with the training they received that supported to development of the business. The mean value of the variable is 3.58. This research reveals that most of the members in the SHGs benefited in the skill development training provided by the intervention. 
According to Narayana (1998), as cited by Nithyanandhana, \&Mansorb,(2015) "Empowerment of women is a process whereby the powerless or disempowered gain a greater share of control of resources and decision-making". The process of gaining control over self, ideology, and resources, which determines power, may also be termed as empowerment. SHGs can act as a provider of skills in decision making. The results of the study illustrated the satisfactory level towards the Decision making ability after the intervention of the Self Help Groups in the study area. Around $8.7 \%$ of the respondents dissatisfied with the decision-making ability while $37.7 \%$ of the respondents moderately satisfied with their decision-making ability. $53.6 \%$ of respondents satisfied with the opinion that they have acquired decision-making ability through the Self-Help Group. The mean value for the variable was 3.43 and confirm that the majority of the members in the SHGs have got decision making power after the involvement of SHG in the study area.

Leadership Qualities is another variable in the research. Respondents' satisfactory level on the leadership quality after the intervention of the Self Help Groups was in the higher level of satisfaction in the study area. The findings illustrate that $2.9 \%$ of the respondents reported that they dissatisfied with increase leadership quality. $27.5 \%$ of respondents moderately satisfied with leadership qualities while nearly three fourth of the respondents $(69.6 \%)$ satisfied with leadership quality. The mean value for the variable is 3.70 . it indicates that most of the respondents have high leadership qualities after the formation of self-help groups approach in the study area.

Community participation' is commonly understood as the collective involvement of local people in assessing their needs and organizing strategies to meet those needs (Zakus\&Lysack, 1998). Many development interventions used a participatory approach for women empowerment. This study also includes the women participation as a variable. The findings illustrate the satisfactory level to the community participation by the respondents after the intervention of Self Help Groups in the study area. The finding demonstrates that no respondents dissatisfied with the community participation. $29 \%$ of the respondents moderately satisfied with the community participation. Two third of the respondents (71\%) satisfied with the community participation. The mean value (3.71) for the variable has confirmed that the women are highly satisfied in the community participation with SHGs in the study area.

\section{Economic Empowerment:-}

SHGs have proved as an effective medium for delivering credit to rural poor for their socioeconomic economic empowerment to effectively improve their well-being and there is significant empowerment in the women empowerment of SHG members (Renuga Devi \& Nirmala Devi, 2017). Table 2 describes the overall analysis of the economic empowerment of women after the intervention of Self Help Groups in the study area.

Table 2:-Overall analysis of Economic Empowerment

\begin{tabular}{|l|c|c|}
\hline \multicolumn{1}{|c|}{ Status of Satisfaction } & No. of respondents & Percentage \\
\hline Dissatisfaction & 01 & 1.4 \\
\hline Moderate Satisfaction & 18 & 26.1 \\
\hline Satisfaction & 50 & 72.5 \\
\hline Total & 69 & 100 \\
\hline Mean & 3.71 & \\
\hline Standard Deviation & .488 & \\
\hline Reliability (Cronbach's Alpha value & .934 & \\
\hline
\end{tabular}

Source:-Field Survey

As per the results, out of respondents, only one (1.4\%) fall under the category of dissatisfaction regarding the economic empowerment of women through the self-help group. $26.1 \%$ of the sample respondents are moderately satisfied while $72.5 \%$ of the respondents are satisfied in terms of the economic empowerment of the women through the self-help group. The mean value of overall analysis for the variable under the economic empowerment discloses the 3.71 with a standard deviation of .457 . Figure 2 shows the summary of the value of each variable that is considered to be contributing to the economic empowerment of women through the self- help group in the study area. 
Figure 2:-Overall Analysis of Economic Empowerment.

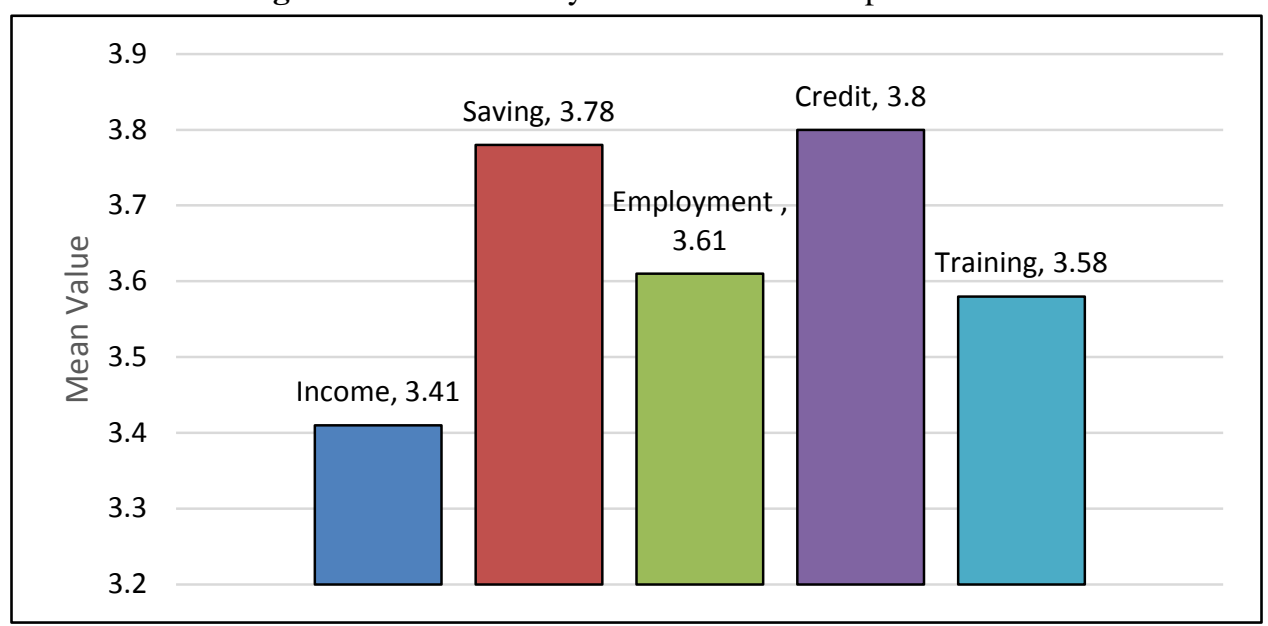

\section{Social Empowerment:-}

Table 3 shows the overall analysis of social empowerment of women by the respondents after the intervention of Self Help Groups

Table 3:-Overall Analysis of Social Empowerment

\begin{tabular}{|l|c|c|}
\hline \multicolumn{1}{|c|}{ Status of Satisfaction } & No. of respondents & Percentage \\
\hline Dissatisfaction & 2 & 2.9 \\
\hline Moderate Satisfaction & 20 & 29 \\
\hline Satisfaction & 47 & 68.1 \\
\hline Total & 69 & 100 \\
\hline Mean & 3.65 & \\
\hline Standard Deviation & .538 & \\
\hline Reliability (Cronbach's Alpha value & .837 & \\
\hline
\end{tabular}

\section{Source:-Survey Data}

The above table 3 reveals that, out of 69, only 2 samples (2.9\%) fall under the category of dissatisfaction regarding the social empowerment of women through the self-help group. $29 \%$ of the sample respondents are moderately satisfied while $68.1 \%$ of the respondents are satisfied in terms of the social empowerment of the women through the self-help group. The mean value of overall analysis for the variable under the social empowerment seems the 3.65 with the standard deviation of .538. The following figure 3shows the summary of the value of each variable that is considered to be contributing to the social empowerment of women through the self- help group

Figure 3:-Comparing the mean value of Social empowerment

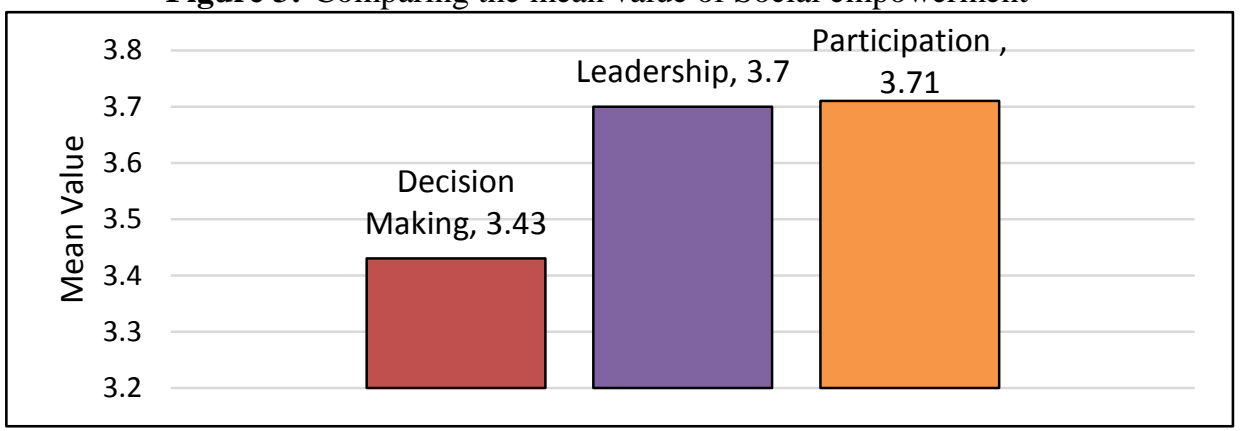

Source:-Survey Data 


\section{Overall Analysis of Socioeconomic Empowerment:-}

Figure 4 says that, out of the respondents, $23.2 \%$ of the respondents are moderately satisfied while $76.8 \%$ of the respondents are satisfied in terms of the contribution of socio-economic empowerment of the rural women. The mean value of overall analysis for socio-economic empowerment is 3.77 with a standard deviation of .425 . Based on these results, it can be understood that the concept of self-help groups have been a success and significantly contributed to the socio-economic empowerment of the rural women in the study area. The following tables show the summary of the value of each variable that contributes to the socio-economic empowerment of rural women in the study area.

Figure 4:-Overall Analysis of Socio-Economic Empowerment

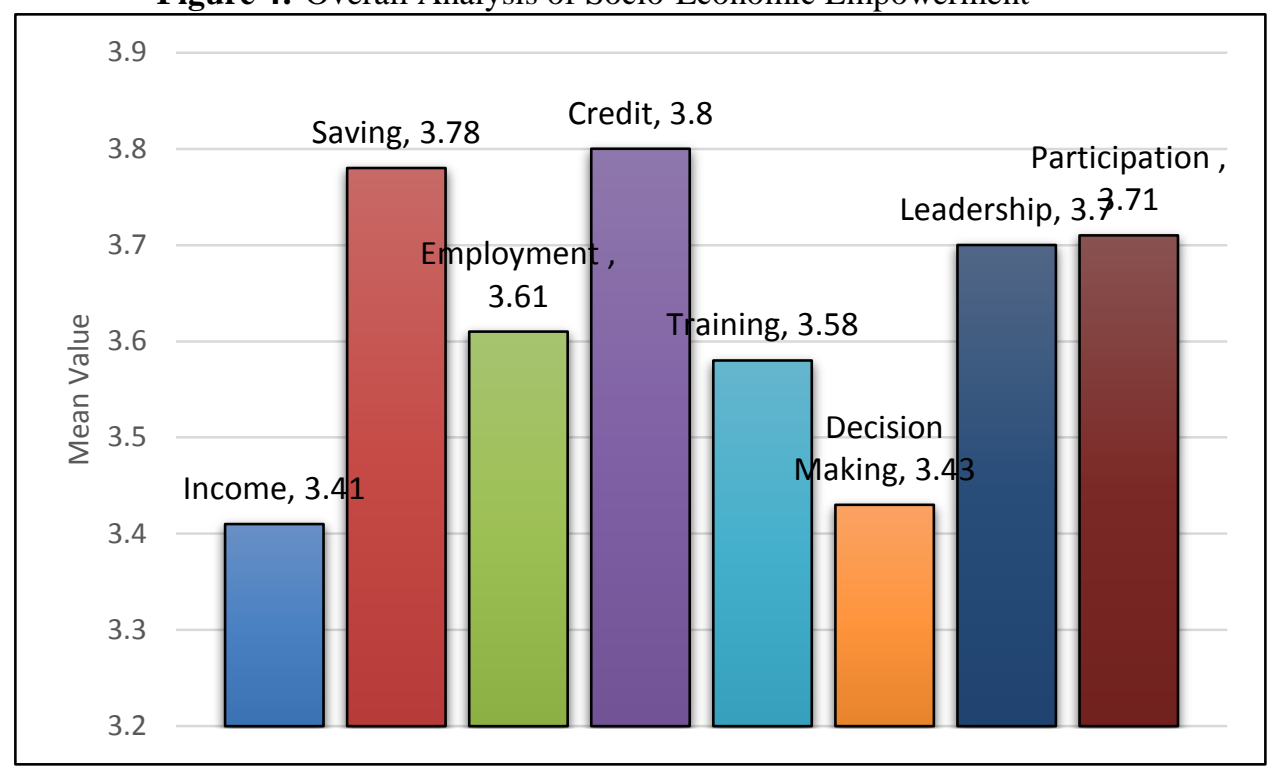

\section{Conclusion:-}

The overall analysis of the data reveals that the self-help group approach has highly contributed to promoting the socio-economic empowerment of rural women. As per the summary of data analysis, out of 69 , no one falls under the category of dissatisfaction regarding the socio empowerment of women through the self-help group. $23.2 \%$ of the respondents are moderately satisfied while $76.8 \%$ of the respondents are highly satisfied in terms of the socioeconomic empowerment of the women through the self-help group. It is confirmed that the Self Help Group is a powerful tool to enrich the savings activities and poverty alleviation and women empowerment could be achieved through Self Help Group interventions.

\section{Acknowledgment:-}

The Authors are very grateful to all contributors for their help toward this research.

\section{References:-}

1. Abdul R., Al Yasmeen,andSolthana .K (2007), World empowerment of women through self-help group a view

2. Sakthisugans Ltd, p. 48

3. Bhatnagar, S., \&Rathore, S. (2015). Social and Economic Empowerment of Rural Women through Self Help Group Formation in Jaipur District of Rajasthan. Journal of Krishi Vigyan, 3(2s), 94. doi: 10.5958/23494433.2015.00044.6

4. Bosch, Ellie (2010), Micro-finance: New Wine in a New Bottle, A Supplementing Role for Cordaid and IICO,

5. Brody, C., Hoop, T., Vojtkova, M., Warnock, R., Dunbar, M., Murthy, P., \&Dworkin, S. (2016). Can self-help

6. group programs improve women's empowerment? A systematic review. Journal of Development

7. Effectiveness, 9(1), 15-40. doi: 10.1080/19439342.2016.1206607

Christuraj P and Saraswathy S (2009), "Self Help Groups and Socio-Economic Changes among Rural Women”,

8. Indian Journal of SocialDevelopment, an International Journal, May, Vol.9, No.1, Pp.1-10. 
9. Devi, S. (2012). Empowerment of Women Entrepreneur through Self Help Groups. International Journal Of Scientific Research, 3(4), 127-129. doi: 10.15373/22778179/apr2014/196

10. Jyothi, G. (2012). Women Empowerment Role of Self Help Groups. Global Journal for Research Analysis, 3(8), 1 doi: 10.15373/22778160/august2014/114

11. Kabeer, Naila (2001) World Development, 29 (1). pp. 63-84 Nithyanandhana, H., \&Mansorb, N. (2015). Self Help Groups and Women's Empowerment. Institutions and Economies, 7(2), 143-164.

12. Renuga Devi, S., \& Nirmala Devi, V. (2017). Economic Empowerment of Rural Women through SHGs with reference to Coimbatore District. International Journal of Engineering Development and Research, 1110-1113.

13. Tandon .T. (2016), Women Empowerment: Perspectives and Views, International Journal of Indian Psychology, Volume 3, Issue 3, No. 8, DIP: 18.01.134/20160303, ISBN: 978-1-365-12176-0

14. Thangamani, S. (2013). A Study on Women Empowerment through Self- Help Groups with Special Reference to MettupalayamTalukIn Coimbatore District. IOSR Journal Of Business And Management, 8(6), 17-24. doi: 10.9790/487x-0861724

15. Sita Devi K Prabakar C and Ponnarasi T (2011), "Impact of Microfinance Innovation in Pushing Back Rural Poverty in Tamil Nadu", Indian Journal of Agricultural economics, July-Sept, Vol.66, No. 3, Pp. 430-443

16. Varathan, D., Kumar, D., \& Dr. K.N. Selvakumar, D. (2011). Impact of Self Help Group Programme on Empowerment of Women through Livestock Rearing in Tamil Nadu. Indian Journal Of Applied Research, 3(2), 71-73. doi: 10.15373/2249555x/feb2013/25

17. Zakus, J. (1998). Review article. Revisiting community participation. Health Policy And Planning, 13(1), 1-12. doi:10.1093/heapol/13.1.1. 